\title{
Manajemen Perubahan Organisasi Dinas Kesehatan dalam Revitalisasi Puskesmas di Kabupaten Sumedang
}

\author{
Nina Triana, ${ }_{1}$ Elsa Pudji Setiawati, ${ }^{2}$ Insi Farisa Desy Arya, ${ }^{2}$ Deni K Sunjaya, ${ }^{2}$ Dadi S Argadiredja, ${ }^{2}$ \\ Dewi Marhaeni Diah Herawati \\ ${ }^{1}$ Dinas Kesehatan Kabupaten Sumedang Indonesia, ${ }^{2}$ Departemen Ilmu Kesehatan Masyarakat Fakultas \\ Kedokteran Universitas Padjadajaran
}

\begin{abstract}
Abstrak
Revitalisasi Puskesmas merupakan upaya Kementerian Kesehatan RI untuk meningkatkan kinerja Puskesmas melalui berbagai perubahan dalam penyelenggaraan Puskesmas. Perubahan-perubahan tersebut sejalan dengan semangat reformasi pembangunan khususnya reformasi otonomi daerah. Penelitian ini bertujuan untuk melakukan eksplorasi manajemen perubahan dalam revitalisasi Puskesmas yang dilakukan oleh Dinas Kesehatan. Metode Desain penelitian yang dipergunakan adalah kualitatif dengan paradigma konstruktivism dan strategi studi kasus. Metode analisis yang digunakan adalah tematik. Subyek penelitian ini adalah kepala dinas kesehatan dan kepala Puskesmas. Hasil Manajemen perubahan Dinas Kesehatan dalam revitalisasi Puskesmas dikonstruksi oleh fungsi-fungsi manajemen perubahan menurut model manajemen kinerja klinis WHO SEA-NURS yang meliputi identifikasi, perencanaan, implementasi, dan evaluasi-umpan balik. Peta konsep yang dihasilkan menunjukkan bahwa pelaksanaan manajemen perubahan tersebut terkonsentrasi pada fungsi implementasi yang merupakan tahap penekanan terhadap berbagai masalah yang mulai muncul dalam tugas perubahan yang harus dilakukan.Simpulan Manajemen perubahan organisasi Dinas Kesehatan Kabupaten Sumedang dalam revitalisasi Puskesmas dilakukan secara pasif menurut kebijakan organisasi yang memayunginya.
\end{abstract}

Kata kunci: Manajemen Perubahan, Revitalisasi Puskesmas

\section{Change Management in Sumedang District Health Office on PHC Revitalization}

\begin{abstract}
Revitalization of PHC is an effort of the Indonesia's Ministry of Health to improve the performance of health centers through various changes in the implementation of PHC reforms. The changes are in line with the spirit of development reform, especially reform of the district autonomy. This study aims to explore the management of change in PHC revitalization undertaken by the Sumedang District Government through the District Department of Health and analyze the management of change by PHC staff. Method This research used qualitative design with constructivism paradigm and case study strategies. The analytical method used was semiotic. The subjects of this study is the head of the district health department and the head of PHC. Results Change management of the District Department of Health constructed by management functions change according to the clinical performance management model WHO SEA-Nurs is the identification, planning, implementation, and evaluation feed back. The management of change in the PHC revitalization by the Sumedang District Health Office to focus on the function of which is the implementation phase of the emphasis on issues to appear in the task changes that should be made. Discussion Management changes in Sumedang Health District Office in revitalizing PHC carried passively by overriding organizational policy.
\end{abstract}

Keywords: Change management, $\mathrm{PHC}$ revitalization

\footnotetext{
Korespondensi:

Nina Triana

Dinas Kesehatan Kabupaten Sumedang

Jl. Kutamaya No. 21 Sumedang 45312

Mobile : 085221589655

Email : ninatriana28@yahoo.com
} 


\section{Pendahuluan}

Departemen Kesehatan RI mengembangkan model pelayanan Puskesmas reformasi pada Tahun 2000. Model tersebut merupakan pelayanan Puskesmas yang sejalan dan disesuaikan dengan pengembangan sistem kesehatan dan semangat reformasi otonomi daerah. ${ }^{1}$ Adapun langkahlangkah pengembangan Puskesmas tersebut dinyatakan sebagai revitalisasi Puskesmas, yang merupakan salah satu upaya untuk membangun fondasi reformasi kesehatan di Indonesia. ${ }^{2}$

Revitalisasi Puskesmas adalah mengembalikan Puskesmas kepada konsep Puskesmas, ketenagaan Puskesmas dan pemenuhan sarana dan peralatan di Puskesmas sesuai nilai-nilai dasar dalam Keputusan Menteri Kesehatan Nomor 128 Tahun 2004 tentang Kebijakan Dasar Puskesmas. $^{3}$ Hasil evaluasi Pada Tahun 2006 menunjukkan bahwa revitalisasi Puskesmas masih merupakan wacana di tingkat nasional dan belum diterima sepenuhnya oleh petugas Puskesmas. ${ }^{3}$ Dalam hal ini, penyelenggaraan Puskesmas kemudian berlangsung secara tidak efektif karena tidak sesuai dengan nilai-nilai dasar yang telah ditentukan. Upaya perbaikan dilakukan oleh Kementerian Kesehatan dengan menyusun strategi untuk melaksanakan revitalisasi Puskesmas sebagai langkah reformasi kesehatan masyarakat sejak Tahun 2010. ${ }^{4}$

Berdasarkan capaian kinerja puskesmas di Kabupaten Sumedang pada Tahun 2013, terdapat indikasi adanya berbagai permasalahan dalam pelaksanaan revitalisasi Puskesmas. Dengan pendekatan konsep kerangka kerja sistem kesehatan masyarakat, maka revitalisasi Puskesmas dapat dipandang sebagai sebuah proses yang akan menghasilkan outcome yang meliputi efektifitas, efisiensi, dan equity. ${ }^{5}$

Pengetahuan tentang alasan bagi terjadinya perubahan dan bagaimana cara memperoleh hasil perubahan memerlukan penjelasan teori perubahan. ${ }^{6}$ Model manajemen perubahan memberikan manfaat dalam menjelaskan penyederhanaan proses perubahan dan mengetahui apa yang tengah terjadi pada suatu organisasi. ${ }^{7}$ Penelitian Mehrolhassani dan Emami, menjelaskan model manajemen perubahan yaitu model Kurt Lewin, mampu menjelaskan reformasi sistim akuntansi dalam sektor kesehatan yang dilakukan di sebuah Universitas di Iran. ${ }^{8}$ Selain itu, proses transformasi organisasi yang merupakan salah satu pendekatan manajemen perubahan organisasi dalam penelitian Rondonuwu dan Trisnantoro berhasil mengeskplorasi perubahan pola keuangan RS Jiwa di Provinsi NTB. ${ }^{9}$

Penelitian ini bertujuan untuk mengeksplorasi manajemen perubahan Dinas Kesehatan dalam revitalisasi Puskesmas di Kabupaten Sumedang.

\section{Metode}

Paradigma penelitian ini adalah konstruktivisme sosial dengan desain penelitian deskriptif kualitatif dan strategi studi kasus. Subyek penelitian adalah Kepala Dinas Kesehatan dan Kepala Puskesmas. Adapun kriteria inklusi pada penelitian ini adalah responden memiliki masa jabatan $>5$ tahun dan kriteria eksklusi yaitu tidak berada di tempat dan tidak bersedia. Penelitian dilakukan pada Bulan Februari-Maret 2015 di Dinas Kesehatan Kabupaten Sumedang. Data dikumpulkan dengan teknik wawancara mendalam, observasi, dan penelaahan terhadap berbagai dokumen terkait. Transkrip wawancara diolah melalui tahap-tahap editing, reduksi, koding, kategorisasi, dan interpretasi. Analisis data dilakukan secara tematik dan untuk menjamin trustworthiness maka dilakukan beberapa metode sesuai saran Guba. ${ }^{10}$ Sebelum dilaksanakan, penelitian ini telah mendapatkan ethical clearance dari Komisi Etik

\section{Hasil}

Tahap identifikasi dilakukan setelah adanya dorongan faktor eksternal yaitu reformasi pembangunan dan reformasi otonomi daerah. PemerintahKabupatenSumedang menanggapinya dengan menerbitkan peraturan daerah tentang pembentukan puskesmas sebagai Unit Pelaksana Teknis Daerah (UPTD) dan tata kerja Puskesmas Tahun 2001. Pola dan tata kerja baru Puskesmas tidak teridentifikasi di Kabupaten Sumedang sehingga peningkatan fungsi Puskesmas terus dilakukan dengan struktur organisasi dan tata kerja yang lama. Struktur lama tersebut tidak menunjukkan unit pelaksana teknis fungsional sebagai pelaksana UKM dan UKP dalam fungsi baru Puskesmas. Struktur organisasi Puskesmas yang lama juga tidak menunjukkan posisi penting Badan Penyantun Puskesmas (BPP).

Pada saat bersamaan, situasi politik telah mendorong perubahan pembiayaan Puskesmas dengan Perda yang mengatur pembebasan biaya retribusi pelayanan kesehatan di Puskesmas bagi seluruh masyarakat. Langkah ini telah memprioritaskan alokasi pembiayaan Kesehatan untuk kegiatan kuratif sehingga peningkatan fungsi Puskesmas yang lebih komprehensif menjadi semakin tertinggal khususnya dalam hal pembiayaan upaya preventif-promotif.

Dalam hal pengaruh internal terhadap identifikasiperubahan, kesimpulanterhadapbelum 
tercapainya target contact rate pasien puskesmas yang dipandang sebagai suatu keberhasilan telah memengaruhi penentuan isu strategis dalam fungsi manajemen perubahan berikutnya yaitu perencanaan perubahan di Puskesmas. Hasil yang diperoleh dari tahap identifikasi memengaruhi perencanaan perubahan, kebijakan perubahan dan kebijakan perencanaan. Struktur organisasi dan tata kerja Puskesmas yang lama sudah tidak sejalan dengan berbagai peraturan perencanaan, dan kondisi tersebut mengakibatkan dominasi perencanaan dilakukan oleh Dinas Kesehatan. Puskesmas tidak merasakan adanya perubahan dan memilah lokus perubahan sehingga tidak terjadi perubahan bersama dan tujuan yang dicapai juga bukan merupakan tujuan bersama karenatidak dilakukan melalui proses kesepakatan

Sebagai bagian dari manajemen, proses perencanan juga merupakan proses kerja sama untuk tujuan yang telah disepakati. ${ }^{12}$ Pendekatan partisipatif dan top down-bottom up dalam perencanaan daerah tidak terjadi pada proses penyusunan rencana strategis dan rencana kerja pembangunan kesehatan termasuk pembangunan Puskesmas. Tanpa keterlibatan Puskesmas dan masyarakat maka perencanaan sektor kesehatan menjadi bersifat teknokratik dan politis. Dalam hal ini Puskesmas tidak memiliki perasaan memiliki terhadap dokumen perencanaan yang ada di tingkat kabupaten.

Kegiatan perencanaan di Puskesmas masih bersifat micro planning tanpa adanya keserasian dengan perencanaan kecamatan. Penyusunan rencana kegiatan dilakukan secara intern sesuai sumber pembiayaan yang diberikan oleh Dinas Kesehatan kabupaten sehingga menghasilkan beberapa dokumen perencanaan. Waktu yang tersedia bagi penyusunan dokumen-dokumen perencanaan tersebut biasanya terbatas sehingga kegiatan yang direncanakan diserahkan kepada para pengelola program dan kerap disamakan dengan perencanaan sebelumnya. Berbagai metode dan teknik perencanaan yang hanya dikuasai oleh perencana di tingkat kabupaten serta

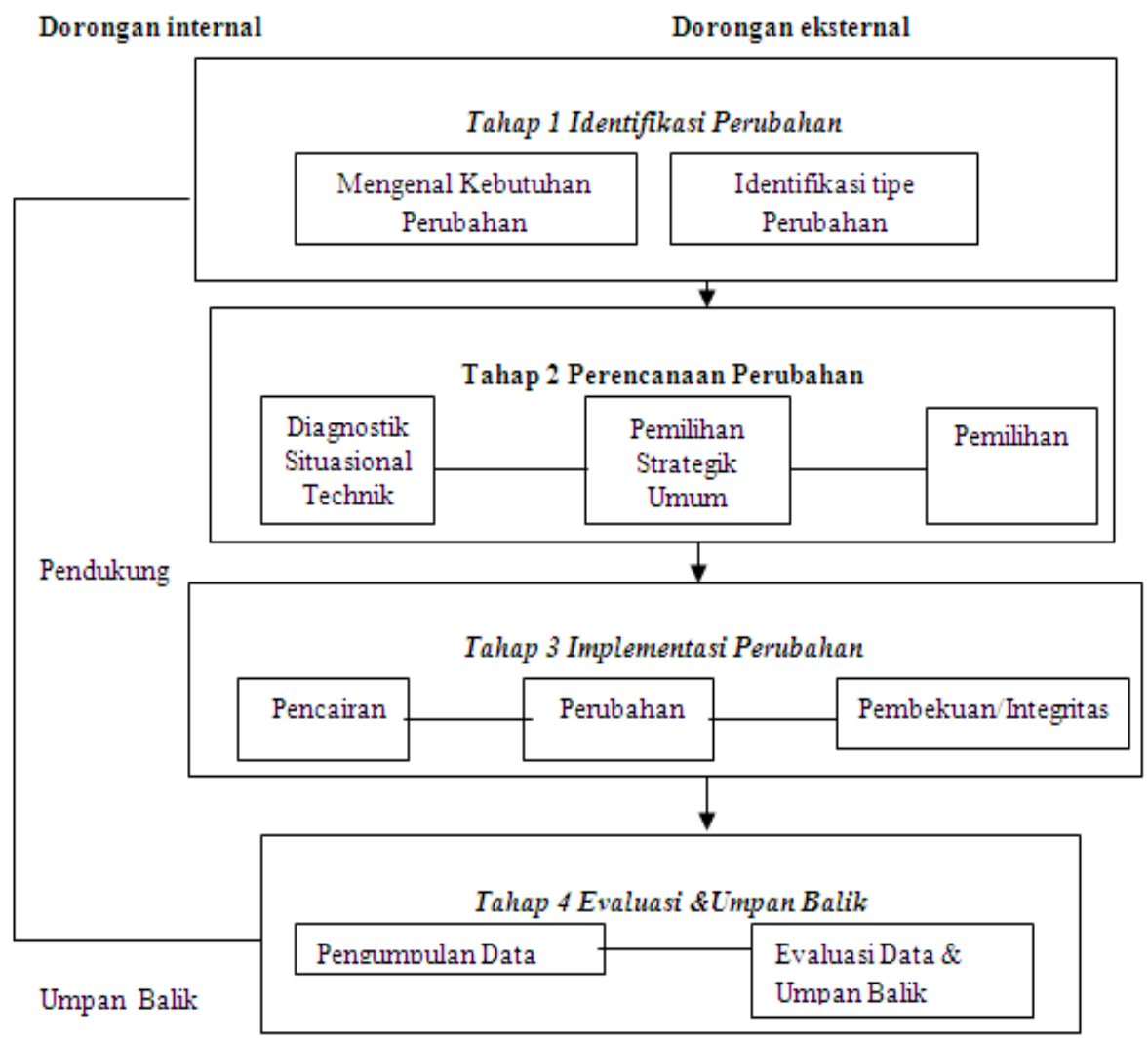

\section{Gambar 1 Tahap-tahap Manajemen Perubahan dalam Sistem Pengembangan Manajemen Kinerja Klinis WHO SEA NURS ${ }^{11}$}


dimensi perubahan yang dipandang tidak secara utuh telah memengaruhi pemilihan berbagai strategi perubahan yang menempatkan Puskesmas sebagai obyek dan bukan subyek perencanaan perubahan. Hal ini dapat menjelaskan fokus perubahan pada dimensi pelayanan yang lebih besar dibandingkan pada dimensi manajemen Puskesmas. Keputusan yang merupakan pilihan strategi perubahan yang akan diimplementasikan lebih banyak dipengaruhi oleh kebijakan anggaran untuk sektor kesehatan dan apa yang menjadi prioritas sehubungan anggaran yang disediakan. Rendahnya contact rate yang disimpulkan sebagai suatu keberhasilan telah menghasilkan daftar isu prioritas dalam Renstra yang tidak secara jelas menangkap masalah penyelenggaraan Puskesmas yang sesungguhnya. Masalah kinerja Puskesmas diselesaikan hanya berdasarkan tujuan normatif pelayanan kesehatan yang tidak komprehensif karena hanya menyangkut aspek kualitas. Pada tahap implementasi, perubahan benarbenar dilakukan dalam bentuk penerapan cara baru yang meliputi bentuk perubahan dalam dimensi pelayanan dan kendali biaya berupa sistem pagu. Berdasarkan teori Kurt Lewin cara baru merupakan tahap pemanasan dalam proses perubahan. Dalam kaitannya dengan analisis medan faktor, pemanasan dapat terjadi apabila faktor-faktor yang mendukung diperkuat atau faktor-faktor yang dinilai menghambat dikurangi. ${ }^{12}$ Dalam implementasi revitalisasi Puskesmas di Kabupaten Sumedang muncul berbagai faktor penghambat sebagai masalah sehingga dilakukan penekanan terhadap berbagai faktor penghambat tersebut sebagai langkah pemecahan masalah. Salah satu faktor penghambat yaitu retensi ternyata justru muncul dari dalam Dinas Kesehatan sendiri terkait hasil analisis Indeks Kepuasan Masyarakat (IKM) yang sangat baik terhadap pelayanan Puskesmas sehingga perencanaan upaya kesehatan masyarakat tidak dijadikan prioritas disamping adanya justifikasi keterbatasan anggaran dan masalah SDM.

Terdapat faktor politik yang menghambat implementasi revitalisasi Puskesmas melalui intervensi terhadap faktor penekan masalah yaitu kebijakan SDM dan kewenangan pimpinan. Faktor politik juga telah mengintervensi tahap perencanaan dan identifikasi melalui kebijakan perencanaan, kebijakan anggaran, dan kebijakan perubahan. Pada masa desentralisasi Dinas Kesehatan kabupaten/kota mendapat tekanan politik terutama dari legislatif dan LSM. ${ }^{13}$ Pemberian instruksi perubahan kepada Puskesmas melalui kepemimpinan dan kewenangan menjadi fase pengubahan dalam implementasi revitalisasi Puskesmas. Mekanisme paksaan dimanfaatkan sebagai alat pengubahan melalui reward dan punishment oleh pimpinan yang berwenang. ${ }^{12}$ Fase pembekuan dalam implementasi revitalisasi Puskesmas di Kabupaten Sumedang dilakukan dalam bentuk penguatan yang berkelanjutan. Penguatan perubahan dalam bentuk ini dalam situasi lingkungan berubah dengan cepat sehingga perubahan baru harus dilakukan pada saat perubahan sebelumnya belum kuat. Dampaknya adalah proses pemunahan perilaku baru relatif segera terjadi. ${ }^{12}$

Tahap evaluasi dan umpan balik sangat ditentukan oleh pengumpulan data, analisa, dan pemanfaatan data. Data tersebut diperoleh dari sistem informasi Puskesmas yang saat ini dikenal sebagai Sistem Informasi Kesehatan (SIK). Tahap evaluasi dan umpan balik menggunakan berbagai instrumen pengumpulan data yang menghasilkan berbagai jenis data untuk dianalisa. Pemanfaatan informasi hasil analisa adalah sebagai alat evaluasi terhadap kinerja. Dimensi kinerja dalam kerangka kerja sistem kesehatan masyarakat yang dikembangkan oleh Bernard Turnock dan Arden Handler meliputi efektifitas, efisiensi, dan ekuitas. ${ }^{5}$ Kebijakan dasar Puskesmas menetapkan bahwa cakupan (coverage), mutu (quality), dan biaya (cost) sebagai rumusan kinerja Puskesmas untuk kepentingan monitoring penyelenggaraan Puskesmas. Pada evaluasi revitalisasi oleh Dinas Kesehatan Kabupaten Sumedang ditetapkan data yang digunakan untuk umpan balik kinerja Puskesmas adalah hasil survey IKM dan laporan cakupan program yang menggambarkan rumusan kinerja berupa cakupan dan kualitas pelayanan kesehatan. Berdasarkan data kinerja Puskesmas, didapatkan bahwa puskesmas lebih cenderung pada sisi cakupan dan kualitas pelayanan kesehatan. Kondisi ini memperlihatkan adanya prioritas dimensi perubahan Puskesmas oleh Dinas Kesehatan. Dalam hal ini perencanaan dan pembiayaan di puskesmas lebih terfokus pada kegiatan pelayanan dibandingkan dengan kegiatan manajemen Puskesmas. Ketidakmampuan suatu institusi pelayanan publik dalam memberikan pelayanan berkualitas dapat disebabkan oleh sarana dan fasilitas yang kurang dan tidak tersedianya SDM profesional. ${ }^{5}$ Perencanaan dan pengalokasian berbagai sumber daya yang ada kemudian lebih fokus bagi kepentingan kegiatan perubahan pelayanan dibandingkan kegiatan perubahan manajemen Puskesmas. Berdasarkan deskripsi hasil penelitian maka didapatkan peta konsep.

\section{Pembahasan}

Manajemen perubahan menjadi cara untuk mencapai hasil yang diharapkan yaitu perubahan 


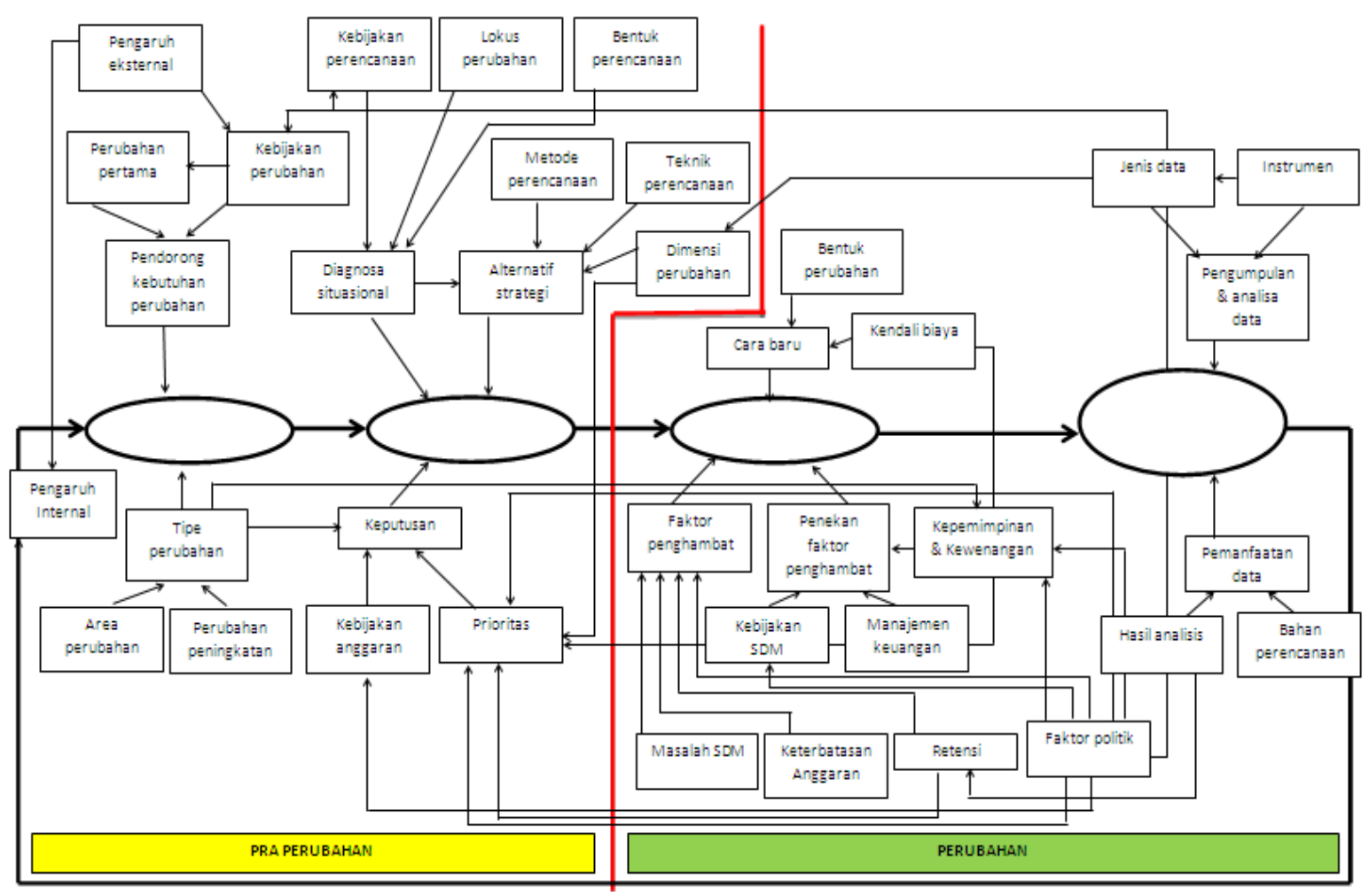

\section{Gambar 2 Peta Konsep Manajemen Perubahan Dinas Kesehatan Kabupaten Sumedang dalam Revitalisasi Puskesmas}

organisasi. Seluruh fungsi yang dilakukan dalam manajemen perubahan menggambarkan proses dalam melakukan perubahan organisasi. Dengan demikian, manajemen perubahan dapat dikatakan sebagai strategi nyata perubahan organisasional. Liebler dan Connel menyatakan bahwa perubahan organisasional adalah suatu proses dimana seseorang atau satu kelompok orang mengembangkan suatu strategi untuk melakukan perubahan dalam sistem sosial. ${ }^{13}$

Peta konsep yang dihasilkan dalam penelitian ini menunjukkan bahwa perubahan Puskesmas sangat tergantung pada ketentuan perubahan dari pemerintah pusat. Kebijakan dasar Puskesmas menjadi filosofi bagi perubahan Puskesmas yang diharapkan. Roadmap reformasi kesehatan masyarakat menunjukkan bahwa Kementerian Kesehatan berupaya mengarahkan perubahan sektor kesehatan sesuai dengan definisi reformasi yang ada yaitu berkelanjutan, terarah, dan mendasar. ${ }^{14}$

Berbagai cara baru telah dilakukan di Puskesmas sesuai arahan Kementerian Kesehatan berupa pembebasan biaya berobat ke Puskesmas termasuk jaminan kesehatan, sumber-sumber baru dan kendali pembiayaan Puskesmas, perubahan kedudukan Puskesmas menjadi UPTD, kebijakan dasar Puskesmas, dan perubahan pemberian pelayanan menjadi komprehensif. Dalam tinjauan tentang efektifitas perubahan hal-hal tersebut menunjukkan pengelolaan tombol perubahan yang meliputi pembayaran, pembiayaan, organisasi, kebijakan, dan perilaku. ${ }^{14}$ Dengan demikian, perubahan mendasar terhadap Puskesmas yang telah dilakukan oleh Dinas Kesehatan sesuai arahan dari Kementerian Kesehatan dapat dikatakan sebagai reformasi dengan $\mathrm{R}$ besar karena melibatkan seluruh tombol pengendali.

Walaupun demikian, Dinas kesehatan melakukan fungsi manajemen perubahan tanpa adanya pendampingan sehingga sejak awal manajemen perubahan tidak berlangsung secara utuh. Hal yang sangat nampak adalah kebutuhan SOTK Puskesmas berdasarkan KMK 128 Tahun 2004 yang mengandung unsur pelaksana teknis fungsional dalam upaya kesehatan Puskesmas dan perwakilan masyarakat dalam BPP tidak diidentifikasi oleh Dinas Kesehatan. SOTK baru tersebut diperlukan agar pada saat implementasi perubahan, Puskesmas telah memiliki kejelasan dalammelaksanakantugaspengembangkanfungsi. Identifikasi pelaksana teknis fungsional bagi 
UKP dan UKM di Puskesmas akan menjelaskan fungsi sebagai pusat pelayanan kesehatan dan menentukan peta kebutuhan maupun formasi SDM Puskesmas. Dengan demikian, jumlah dan kualitaspengelolaperubahanuntukpengembangan fungsi Puskesmas dapat direncanakan dengan baik. Sementara itu, melibatkan masyarakat dalam perumusan, pelaksanaan, dan evaluasi kebijakan Puskesmas dalam wadah BPP akan menjelaskan konsep perubahan Puskesmas dalam fungsi sebagai pusat penggerak pembangunan kesehatan. Kehadiran masyarakat dalam pola dan tata kerja Puskesmas juga akan memperjelas perubahan fungsi Puskesmas dalam membina peran serta masyarakat (PSM) menjadi fungsi pusat pemberdayaan masyarakat.

Perubahan organisasi merupakan salah satu tombol pengendali yang dapat mempengaruhi kinerja sistem kesehatan. Tombol pengendali ini dapat dimodifikasi dengan kebijakan publik. ${ }^{15}$ Ketiadaan kebijakan baru dalam hal organisasi dan tata kerja Puskesmas untuk peningkatan kinerja yang diharapkan telah mengaburkan fungsi identifikasi perubahan Puskesmas sehingga memengaruhi optimalisasi fungsifungsi perubahan berikutnya. Keterbatasan penelitian ini adalah triangulasi sumber hanya dilakukan dalam lingkup unit penelitian sehingga data manajemen perubahan organisasi tidak berasal langsung dari perencana reformasi sektor kesehatan yang berada di level pemerintah pusat, Peneliti tidak melakukan pendampingan perubahan dan penelitian ini bersifat restropektif sehingga hanya melihat proses perubahan yang sudah dilakukan, Konteks penelitian ini adalah penyelenggaraan revitalisasi Puskesmas sebelum terbitnya Permenkes No. 75 Tahun 2014 tentang Puskesmas.

Kesimpulan penelitian ini adalah Manajemen perubahan Dinas Kesehatan Kabupaten Sumedang dalam revitalisasi Puskesmas dilakukan secara pasif menurut kebijakan organisasi yang memayunginya.

Saran yang diberikan berdasarkan hasil penelitian adalah Bagi Kementerian Kesehatan perlu menyediakan pedoman pelaksanaan revitalisasi Puskesmas disertai pendampingan bagi Dinas Kesehatan kabupaten. Bagi pemerintah daerah perlu menetapkan struktur organisasi dan tata kerja Puskesmas yang mengakomodir perkembangan fungsi Puskesmas.

\section{Daftar Pustaka}

1. Departemen Kesehatan Republik Indonesia. Laporan akhir puskesmas era desentralisasi dalam pengembangan sistem kesehatan kabupaten/kota (Tahap I : analisis situasi). Jakarta: Departemen Kesehatan RI; 2002.

2. Departemen Kesehatan Republik Indonesia. Membangun fondasi reformasi kesehatan: rekaman pembangunan kesehatan periode 1999-2004. Jakarta: Departemen Kesehatan RI; 2004.

3. Departemen Kesehatan Republik Indonesia. Laporan akhir penelitian upaya revitalisasi pelayanan kesehatan Puskesmas dan jaringannya dalam rangka peningkatan kualitas pelayanan kesehatan. Surabaya: Departemen Kesehatan R.I;2006.

4. Keputusan Menteri Kesehatan Republik Indonesia tentang Penetapan Roadmap Reformasi Kesehatan Masyarakat, 267 (2010).

5. Setiawati EP. Nadeak W, Sendjaja TP, Djajasudarma F, Kurnani BA, Hariyadi D, Wahya, Sobarna C, Indira D, editor. Peranan sumber daya terhadap pencapaian kinerja program penanggulangan Tuberkulosis. Bandung: UNPAD Press; 2010.

6. Clark H, Anderson AA. Theories of change and logic models: telling them apart; 2004 [diunduh 2014/11/4]. Tersedia dari: http:// www.theoryofchange.org.

7. Afiff F. Alternatif model manajemen perubahan [diunduh 9 Oktober 2014]: Tersedia dari: fe.unpad.ac.id.

8. Mehrolhassani MH, Emami M. Change theory for accounting system reform in health sector: a case study of Kerman University of medical science in Iran. International $\mathbf{J}$ of Health Policy and Management. 2013 [diunduh 9 Oktober 2014]; I(4):279-85. Tersedia dari : http://www.ncbi.nlm.nih.gov/ pubmed.

9. Rondonuwu J, Trinantoro L. Manajemen perubahan di lembaga pemerintah: studi kasus implementasi kebijakan pelaksanaan PPK-BLUD di Rumah Sakit Jiwa Provinsi NTB. J Kebijakan Kesehatan Indonesia. 2013;02:163-70. 2013 [diunduh 22 Oktober 2014]. Tersedia dari: http://jurnal.ugm.ac.id.

10. Shenton, AK. Strategies for ensuring trustworthiness in qualitative research projects. J Education For Information. 2004 [diunduh 20 Oktober 2014]; 22:63. Tersedia dari : http://www.crec.co.uk.

11. WHO SEA-NURS. Manajemen perubahan: materi pelatihan keterampilan manajerial SPMK. Jakarta: WHO SEA-NURS; 2003 [diunduh 4 November 2014]. Tersedia dari : https://docs.google.com.

12. Hersey P, Blanchard K. Manajemen perilaku organisasi : Pendayagunaan sumberdaya 
manusia. Jakarta; Erlangga; 1994.

13. Sunjaya DK. Perubahan organisasional dinas kesehatan, Studi kasus peningkatan fungsi regulasi Dinas Kesehatan Kota Bandung dan Kota Yogyakarta. Program Doktor Ilmu Kedokteran dan Kesehatan Fakultas kedokteran Universitas Gadjah Mada;2010.

14. Berman PA, Bossert TJ. A Decade of Health Sector Reform in Developing Countries:
What Have We Learned? Data for Decision Making Symposium; Washington DC: Data for Decision Making Project by USAID; 2000 [diunduh 11 Oktober 2014]. Tersedia dari : https://www.hsph.harvard.ed.

15. Roberts M, Hsiao W, Berman P, Reich M. Getting health reform right a guide to improving performance and equity [e-book]. New York: Oxford University Press;2008. 